\title{
The effect of competitive strategies on company performance with supply chain management as moderating variables in Indonesian manufacturing corporations
}

\author{
Dadang Hermawan $^{\mathrm{a}^{*}}$
}

\begin{tabular}{l}
${ }^{a}$ ITB STIKOM, Bali, Indonesia \\
\hline C H R O N I C L E \\
\hline Article history: \\
Received November 8, 2020 \\
Received in revised format \\
January, 28, 2021 \\
Accepted March 242021 \\
Available online \\
March 25 2021 \\
\hline Keywords: \\
Competitive Strategy \\
Firm Performance \\
Supply Chain Management
\end{tabular}

\section{Introduction}

In today's global economic conditions and the emergence of new developing companies with conditions of intense competition in the business environment, every company must have the potential to compete. A company can be said to outperform other companies if it can create products with high selling value, good quality and fast distribution of goods so as to attract the attention and interest of consumers (Siagian, 2005). Hence, companies must be more responsive to consumer needs and market demands. Along with these conditions, the company needs a competitive strategy in order to maintain a position in the market. And with the existence of a competitive strategy within the company, it is expected that the company can maintain its competitive position against competitors (Simchi-Levi et al., 2008). This forces an organization to continuously carry out an innovation in achieving competitive advantage by creating products that are unique and have a fast delivery strategy. For that we need a business network, namely supply chain management in order to achieve one of the company goals, namely increasing company performance. Performance is a measure of the success or achievement a company has achieved which is measured within a certain period of time (Li et al., 2006; Anton, 2010). Supply Chain Management is a process of applying how the network of production and distribution activities can work together to meet market demand. According to Robert \& Vijay (2012), Supply Chain Management (SCM) is an integration of activities for procurement of materials and services, conversion of semi-finished goods into final products, and delivery to customers. Supply Chain Management (SCM) is more suitable for manufacturing companies because manufacturing companies are companies that produce raw materials into finished goods that are ready for consumption. Supply Chain Management (SCM) is a concept concerning product distribution patterns that can replace product distribution patterns optimally and is also a further development of product distribution management to meet consumer demand (McLeod, 1996). This concept emphasizes an integrated concept that concerns the process of product flow from suppliers, manufacturers, retailers to

\footnotetext{
* Corresponding author

E-mail address: dhermawan.stikombali@gmail.com (D. Hermawan)

C 2021 by the authors; licensee Growing Science.

doi: $10.5267 /$ j.uscm.2021.3.009 
consumers, from here the activities between suppliers and final consumers are one unit without a large barrier so that the information mechanism between the various elements takes place transparently (Perry II, 2012).

This research is motivated Suhartati and Rosietta (2012), Ghatebi et al. (2013), Ulfa (2015) and Adha (2017) demonstrating that first, there is a positive and significant relationship between Supply Chain Management and company performance; second, it is proven that strategies have an effect on strengthening the relationship between Supply Chain Management (SCM) and company performance; third, there is a significant positive relationship between low cost competitive strategy (cost efficiency) and Supply Chain Management (SCM). Then, there is a significant negative relationship between the competitive innovation strategy (innovation) and Supply Chain Management (SCM). The problems in this research are: (1) Can competitive strategy affect company performance? (2) Can supply chain management affect company performance? (3) Can the competitive strategy affect the company's performance with the supply chain variable as a moderating variable? The purpose of this study was to determine the effect of competitive strategies and supply chain management on company performance. As well as to determine the effect of supply chain management in moderating the relationship between competitive strategies and company performance in manufacturing companies on the Indonesia Stock Exchange for the 2015-2019 period.

\section{Theoretical Framework and Hypothesis}

\subsection{The Influence of Competitive Strategy on Company Performance}

Selection of the right strategy is a part that needs to be considered in the company to create value for consumers in order to generate competitive advantage for the company (Raharjo, 2007). Companies that have the right strategy and can adapt to each function activity in the organization and are unique in serving consumer demand, then these consumers will provide more value to the company so that what is targeted in the company can be fulfilled, namely improving company performance (Davis et al., 1997). According to Rahmasari (2011) and Ellinger et al. (2011) previous research, competitive advantage has a significant effect on company performance and according to research by Suharto (2013) and Tewal (2010) it shows that there is a significant positive influence between competitive strategy and company performance. Based on the description, the following hypothesis can be taken:

\section{Hypothesis 1: Competitive strategy has a significant positive effect on company performance}

\subsection{The Effect of Supply Chain Management on Company Performance}

Performance is the work ability shown from the work of a company that is market-oriented and aims to achieve profit. Optimization of company performance can be achieved if there is a working relationship or good cooperation between the actors, namely: suppliers, factories, distributors, sellers and customers, so that performance becomes one of the aspects that can be measured in supply chain management. With the existence of Supply Chain Management or supply chain management, the performance measurement system can run well and it is hoped that companies can make continuous improvements because Supply Chain Management or supply chain management teaches how to form a good organizational network and business processes. So that to improve company performance can be supported by increasing the implementation of supply chain management (Suharto, 2013). According to previous research, Suhartati and Rosietta (2012) state that there is a positive and significant relationship between supply chain management and company performance and according research to Rahmasari (2011) shows that there is a significant effect of supply chain management on company performance. Based on the description, the following hypothesis can be taken:

\section{Hypothesis 2: Supply chain management has a significant positive effect on company performance}

\subsection{The Influence of Competitive Strategy on Company Performance with Supply Chain Management as a Moderating Variable}

The term Supply Chain Management (SCM) was first coined by Oliver \& Weber (1982), where SCM is an integrated method, tool or approach based on a spirit of collaboration with the aim of satisfying end consumers so that companies must work together to make cheap products, deliver it on time and in good quality. One of the keys to the success of a company in competition is to have and maintain a competitive advantage which lies in the company's ability to differentiate itself from its competitors and the ability to produce at a lower cost (Wheelen et al., 2017). Competitive advantage through value advantage will determine the company's success in business competition (Le Roy \& Czakon, 2016). In fact, consumers do not buy goods but buy certain benefits that are in an item. Therefore, companies must be able to differentiate their products from competitors' products, one of which is by implementing Supply Chain Management (Chang et al., 2015; Gitman \& Zutter, 2012). According to Render and Heizer (2005), the application of SCM (Supply Chain Management) which follows the correct SCM concept can have an impact on increasing competitive advantage on products and on the supply chain system built by the company. Render and Heizer (2005) further stated that companies need to consider supply chain issues to ensure that the supply chain supports the company's competitive strategy. If operations management supports the overall 
corporate strategy, then the supply chain is designed to support operations management. This is supported by the opinion of Chopra \& Meindl (2007), Wright et al., (2009) which states that supply chain design, planning, and operational decisions play an important role in determining the success or failure of an organization. According to previous research, Suhartati \& Rosietta (2012) stated that it is proven that supply chain management has an effect on strengthening the relationship between competitive strategy and company performance. Based on the description, the following hypothesis can be taken:

Hypothesis 3: Supply chain management has a significant positive effect in strengthening the relationship between competitive strategies and company performance

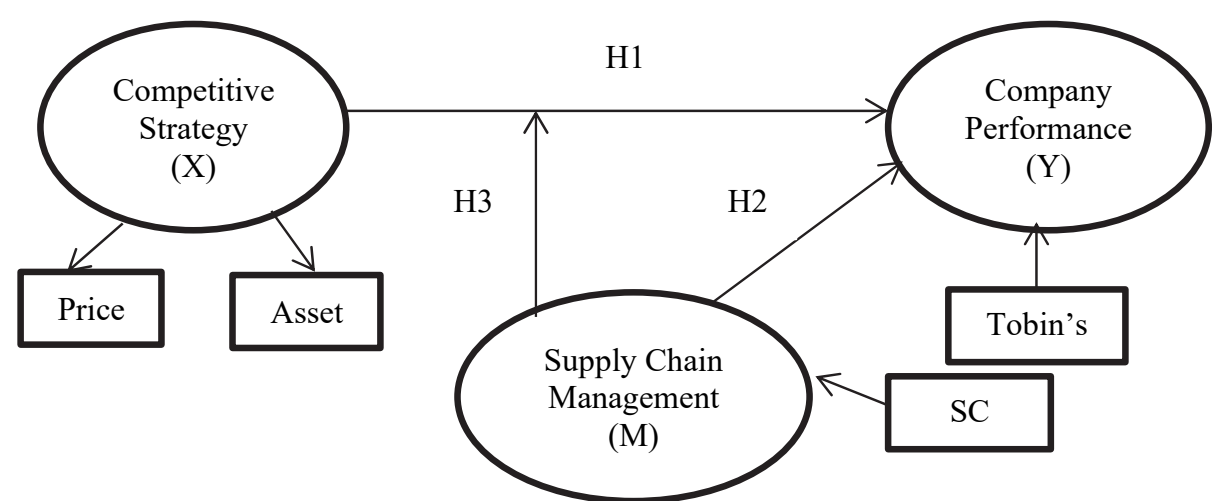

Fig. 2. Research Framework

\section{Research Methods}

\subsection{Sample and Data Classification}

The population in this study is manufacturing companies listed on the Indonesia Stock Exchange (BEI) in 2015-2019. The population was chosen because manufacturing companies are companies that process raw materials into finished goods. By optimizing the supply chain management strategy, manufacturing companies can benefit from reducing inventory, ensuring the smooth supply of goods, reducing the number of suppliers, ensuring quality and developing supplier partnerships. Sampling in this study using purposive sampling method with the aim of getting a representative sample according to the following criteria: (1) Publish audited financial statements for the period 2015-2019 consistently, sequentially and completely. (2) Has the necessary components as a measurement of research variables. (3) Financial reports use the Rupiah currency. From the research criteria, it was obtained by 258 companies that became the research sample. The data used in this research is quantitative data. Data collection techniques for the purposes of this study were carried out with documentation. The documentation that is done is to collect all secondary data in the form of closing prices, number of outstanding shares, total debt, inventory, current assets, total company assets, total sales revenue, gross profit, net cash flow from operations and current liabilities. All data was obtained from www.idx.co.id and the webpages of each sample company by looking at audited financial reports and company performance. The research variables used in this study include the dependent variable, namely company performance, the independent variable, namely competitive strategy, and the moderating variable, namely supply chain management. To test the relationship between competitive strategies on company performance with supply chain management as a moderating variable using the Partial Least Square (PLS) test tool with SmartPLS version 2.0 software.

\subsection{Operational Definition of Variables}

Company performance is a measure in assessing whether a company is healthy or not. A company can run well because it has a good company performance, so that it can meet what is expected by the company, shareholders and creditors (Blose $\&$ Shieh, 1997). Company performance is measured using Tobin's Q ratio. The ratio of the company's market value (market capitalization) divided by total assets. Tobin's Q is calculated by comparing the ratio of the company's stock market value to the book value or the acquisition cost of company equity (Bharadwaj et al., 1999). Tobin's Q formula is as follows:

$$
\mathrm{CP}=\frac{(M E+D E B T)}{\text { Total Assets }}
$$

Note: CP: Company performance; ME: Equity market value (closing price $\times$ number of ordinary shares outstanding); DEBT: (Total Liabilities + Inventories - Current Assets); TA: Total company assets

Competitive strategy is a function of the company in developing and using new core competencies faster than competitors to imitate current competitive advantages (Rasid et al., 2014). This study uses two competitive strategies, namely the low- 
cost strategy (low cost) and differentiation. Competitive strategy is measured using two strategic measures, namely asset utilization efficiency and price premium capability. Based on Jermias \& Gani (2004) the formula for calculating competitive strategies is as follows:

$$
\begin{gathered}
\text { Asset Utilization Efficiency }=\frac{\text { Total Sales Revenue }}{\text { Total Assets }} \\
\text { and } \\
\text { Price Premium Capability }=\frac{\text { Gross Margin }}{\text { Total Sales Revenue }}
\end{gathered}
$$

Lastly, supply chain management is an approach used to achieve a more efficient integration of various organizations from suppliers, manufacturers, distributors, retailers and customers. This means that goods are produced in the right amount, at the right time with the aim of achieving the minimum cost of the overall system and also achieving the desired service level (Pujawan, 2005). Supply chain management is measured using financial ratios, namely the multiplication of cash generation measures and asset efficiency. The formula for calculating supply chain management according to Suhartati \& Rosietta (2012) is as follows:

\section{Results}

$$
\text { Supply Chain Management }=\frac{\text { Net Cash Inflow From Operations }}{\text { Total Assets-Current Liabilities }}
$$

\subsection{Descriptive Statistics}

Descriptive analysis is used to describe the sample data that has been obtained for each research variable without intending to make general conclusions. Descriptive statistical analysis was conducted to find the maximum value, minimum value, average value and standard deviation. This applies to all variables contained in the study, both the dependent variable and the independent variable.

Table 1

$\underline{\text { Results of the Descriptive Analysis of Competitive Strategy Indicators }}$

\begin{tabular}{ccccccccc}
\hline Year & \multicolumn{2}{c}{ Maximum } & \multicolumn{2}{c}{ Minimum } & \multicolumn{2}{c}{ Mean } & \multicolumn{2}{c}{ Std. Deviation } \\
\cline { 2 - 9 } & Asset UEF & $\begin{array}{c}\text { Price } \\
\text { Premium }\end{array}$ & Asset UEF & $\begin{array}{c}\text { Price } \\
\text { Premium }\end{array}$ & Asset UEF & $\begin{array}{c}\text { Price } \\
\text { Premium }\end{array}$ & $\begin{array}{c}\text { Asset UEF } \\
\text { Price } \\
\text { Premium }\end{array}$ \\
\hline 2015 & 2.271 & 0.565 & 0.028 & -0.739 & 1.112 & 0.201 & 0.523 & 0.182 \\
2016 & 2.279 & 0.573 & 0.059 & -0.281 & 1.052 & 0.178 & 0.471 & 0.149 \\
2017 & 2.051 & 0.661 & 0.021 & -1.291 & 0.998 & 0.189 & 0.443 & 0.217 \\
2018 & 2.183 & 0.638 & 0.037 & -1.352 & 0.971 & 0.197 & 0.518 & 0.194 \\
2019 & 2.216 & 0.671 & 0.042 & -1.294 & 1.104 & 0.211 & 0.498 & 0.183 \\
\hline
\end{tabular}

Source: Data processed, 2021

Based on Table 1 for 2015, the maximum value of the Asset Utilization Efficiency indicator is 2.271, 2016 is $2.279,2017$ is $2.051,2018$ is 2.183 and 2019 is 2,216. As for the minimum value of the Asset Utilization Efficiency indicator with a value of 0.028 in 2015, 0.059 in 2016, 0.021 in 2017, 0.037 in 2018 and 0.042 in 2019. For the maximum value of the Price Premium Capability indicator in 2015 amounted to $0.565,2016$ amounted to $0.573,2017$ amounted to .661, 2018 amounted to 0.638 and in 2019 amounted to 0.671 . Meanwhile, the minimum value of Price Premium Capability is -0.739 in 2015 , 0.281 , in 2016, -1.291 in 2017, -1.352 in 2018 and -1.294 in 2019. The average competitive strategy indicator per year in manufacturing companies, namely for the highest average Asset Utilization Efficiency was obtained in 2015 with a value of 1.112 and for the highest average Price Premium Capability was obtained in 2019 with a value of 0.211 . So that the overall average from 2015-2019 with a sample size of 258 companies for the Asset Utilization Efficiency indicator is 1.047 with a standard deviation value of 0.481 and for the Price Premium Capability indicator is 0.195 with a standard deviation of 0.191. Because the standard deviation value of the Asset Utilization Efficiency indicator and the Price Premium Capability indicator is smaller than the average value, it can be concluded that the value of the Asset Utilization Efficiency indicator and the Price Premium Capability indicator has a low deviation level which means the lower the level of deviation then the lower the data variation, So it can be said that the Utilization Efficiency indicator and the Price Premium Capability indicator have good data distribution. Based on table 2, it can be seen that the maximum value of Tobin's Q for 2015 was 3.371 , in 2016 it was 3.251 , in 2017 it was 2.921 , in 2018 it was 3.264 and in 2019 it was 3.353. Meanwhile, the minimum value for Tobin's Q is -0.312 in $2015,-0.185$ in 2016, -0.192 in 2017, -0.213 in 2018 and -0.264 in 2019. The table also shows that the value of Tobin's Q average in 2015-2019 has increased and decreased every year. It is proven that in 2015 the average Tobin's Q value was 1.151 and in the following year, 2016, it increased to 1.201, in 2017 it decreased to 0.987 , in 2018 it increased to 1.006 and lastly in 2019 it increased to 1.035. So that the average overall Tobin's Q value from $2015-$ 2019 is 1.076 with a standard deviation of 0.753 . Because the value of Tobin's Q standard deviation is smaller than the 
average value, it can be concluded that the Tobin's Q average value has a low deviation level, which means that the lower the deviation level, the lower the data variation.

Table 2

Results of Descriptive Analysis of Company Performance Indicators (Tobin's Q)

\begin{tabular}{ccccc}
\hline Year & Maximum & Minimum & Mean & Std. Dev \\
\hline 2015 & 3.371 & -0.312 & 1.151 & 0.741 \\
2016 & 3.251 & -0.185 & 1.201 & 0.792 \\
2017 & 2.921 & -0.192 & 0.987 & 0.711 \\
2018 & 3.264 & -0.213 & 1.006 & 0.697 \\
2019 & 3.353 & -0.264 & 1.035 & 0.709 \\
& $2015-2019$ & & 1.076 & 0.753 \\
\hline
\end{tabular}

Source: Data processed, 2021

Table 3

Results of the Descriptive Analysis of Supply Chain Management Indicators (Ratio SC)

\begin{tabular}{ccccc}
\hline Year & Maximum & Minimum & Mean & Std. Dev \\
\hline 2015 & 0,472 & $-0,219$ & 0,081 & 0,129 \\
2016 & 0,461 & $-0,301$ & 0,074 & 0,141 \\
2017 & 0,489 & $-1,923$ & 0,045 & 0,293 \\
2018 & 0,492 & $-1,875$ & 0,062 & 0,263 \\
2019 & 0,502 & $-1,989$ & 0,057 & 0,272 \\
& $2015-2019$ & & 0,064 & 0,216 \\
\hline
\end{tabular}

Source: Data processed, 2021

Based on Table 3, it can be seen that the value of the SC ratio in 2011 was 0.46902 , then in 2012 it was 0.45874 , and in 2013 it was 0.49187 . Whereas the minimum value of the SC Ratio in 2015 was -0.219 , then in 2016 it was -0.301 , in 2017 it was $-1,923$, in 2018 it was $-1,875$ and in 2019 it was $-1,989$. The amount of the average value of the SC Ratio for the period 2015-2019 has increased and decreased, as evidenced in 2015 the average was 0.081 , in 2016 it fell to 0.74 , in 2017 it fell again to 0.045 , in 2018 it increased to 0.062 and year 2013 rose to 0.057 . So that the overall average from $2015-2019$ is 0.064 with a standard deviation of 0.216 . Because the standard deviation value is greater than the average value, it can be concluded that the average value of the SC ratio has a fairly high deviation level, which means that the higher the deviation level, the higher the data variation, so it can be said that supply chain management has not very good data distribution

\subsection{Outer Model Test Results}

For examining outer model evaluation with reflexive indicators, in this study, the competitive strategy is a construct with reflexive indicators, namely the Asset Utilization Efficiency indicator (low-cost strategy) and the Price Premium Capability indicator (differentiation strategy). For this reason, it is necessary to test the following convergent validity, discriminant validity, and composite reliability for reflexive indicators.

Table 4

Outer Model Test Results for Reflexive Indicators

\begin{tabular}{|c|c|c|c|c|c|c|c|}
\hline \multirow[t]{5}{*}{ Indicator } & \multicolumn{4}{|c|}{ Competitive Strategy } & \multirow[t]{5}{*}{ Variable } & \multicolumn{2}{|c|}{ Composite Reliability } \\
\hline & \multicolumn{2}{|c|}{ convergent validity } & \multicolumn{2}{|c|}{ discriminant validity } & & & \\
\hline & No & With & No & With & & No & With \\
\hline & Moderation & Moderation & Moderation & Moderation & & Moderation & Moderation \\
\hline & Effect & Effect & Effect & Effect & & Effect & Effect \\
\hline AUE & 0.728 & 0.728 & 0.728 & 0.728 & \multirow{2}{*}{$\begin{array}{c}\text { Competitive } \\
\text { Strategy }\end{array}$} & \multirow[t]{2}{*}{0.739} & \multirow[t]{2}{*}{0.739} \\
\hline $\mathrm{PPC}$ & 0.812 & 0.812 & 0.812 & 0.812 & & & \\
\hline
\end{tabular}

Source: Data processed by PLS, 2021

Based on Table 4, the outer model table without a moderation effect or the outer model table with a moderating effect shows that there is no difference in the value of convergent validity on the reflexive indicators, namely the Asset Utilization Efficiency (AUE) indicator and the Price Premium Capability (PPC) indicator. This states that the Asset Utilization Efficiency (AUE) indicator and the Price Premium Capability (PPC) indicator both produce a value of $>0.70$ with the same number of 0.728 for the Asset Utilization Efficiency (AUE) indicator and 0.812 for the Price Premium Capability indicator (PPC), so it can be concluded that all reflexive indicators are declared valid. Furthermore, from the discriminant validity table which can be seen from the cross-loading value, either without a moderating effect or by using a moderation effect, it shows that the value of cross-loading for the reflexive indicators of competitive strategy (AUE and PPC) has the same value, namely the value of cross-loading for the construct of competitive strategy is higher than for other constructs. This can be 
seen from the cross-loading value of AUE to the competitive strategy of 0.728 . The same thing is also seen in the PPC indicator to the competitive strategy, which is 0.812 . Thus, latent constructs predict reflexive indicators in their block better than indicators in other blocks. In addition, because the cross-loading value of the reflexive indicators of AUE and PPC has a value of $>0.70$, it can be said that the indicator is valid. Finally, for the reliability test table which can be seen from the composite reliability value either without a moderating effect or by using a moderating effect, it shows that the value of the composite reliability is a reflexive indicator, namely the construct of competitive strategy has the same value, namely 0.739 , because composite reliability has a value 0.70 , so that It can be concluded that the construct is reliable or meets the reliability test.

\subsection{Outer Model Evaluation with Formative Indicators}

In this study, company performance and supply chain management are constructs with formative indicators, namely the Tobin's Q indicator for company performance constructs and supply chain ratio indicators for the construct of Supply Chain Management (SCM). Outer model with formative indicators is evaluated through its substantive content, namely by comparing the relative weight and seeing the significance of the construct indicators (Ghozali, 2012). From the results of data processing using SmartPLS version 2.0, the results as shown in Fig. 1 and Fig. 2 were obtained.

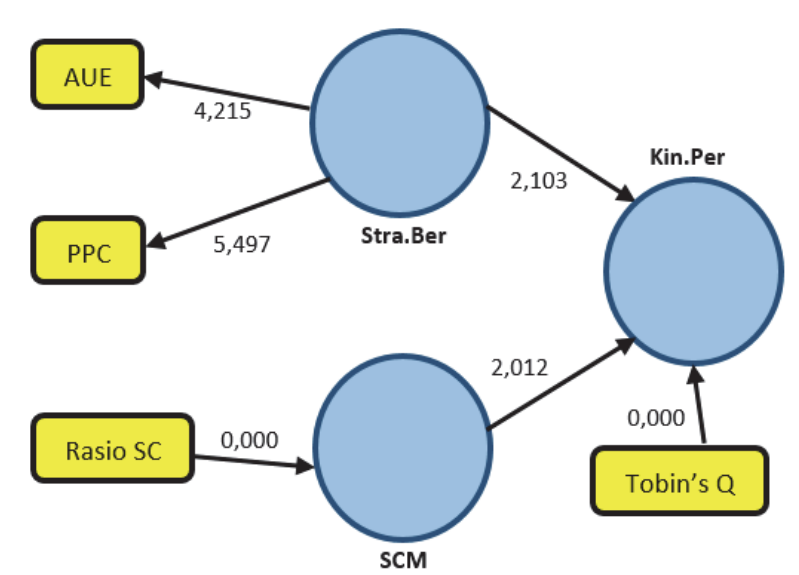

Fig. 3. Outer Weight Value Diagram without Moderation Effect

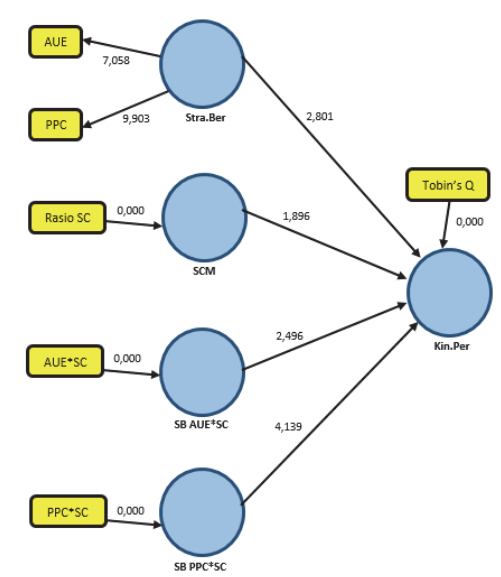

Fig. 4. Outer Weight Value Diagram with Moderation Effect

From the outer weight diagram image, both the outer weight diagram without a moderating effect and the outer weight diagram with a moderating effect show the same results, namely the formative indicator consisting of the Tobin's Q indicator and the SC ratio indicator on the model without a moderating effect as well as additional SB interaction indicators. AUE $\times$ SC and SB PPC $\times$ SC in a model with a moderating effect, all the formative indicators that show the direction of the arrow from the indicator to the construct have a value of 0.000 . This is because Tobin's $\mathrm{Q}$ is the only indicator of the company's performance construct and the SC ratio is the only indicator of the supply chain management construct so that the evaluation of outer weight values which should have criteria $>1.96$ does not need to be discussed, because each of these indicators does not have a comparative indicator so that it has a value of 0.000 (Ghozali, 2012).

\subsection{Inner Model Test Results}

Table 5

Inner Model (R-Square) Results without Moderation and with Moderation

\begin{tabular}{ccc}
\hline Model & Variable & $R$ Square \\
\hline Without Moderation & Company Performance & 0.071 \\
& Supply Chain Management & 0.223 \\
With Moderation & Competitive Strategy & \\
& Company Performance & MDE ${ }^{*} C$ \\
& $M D R P C C^{*} S$ \\
& Supply Chain Management \\
Competitive Strategy
\end{tabular}

From the results of Table 5, it can be seen that the resulting R-Square value in the research model without a moderating effect and the research model with a moderating effect has different results. The results showed that R-square without a moderating effect from table 5 it can be seen that the R-Square value is 0.071 , which means that the influence of competitive strategy variables and supply chain management on company performance can be explained by $7.1 \%$ and the remaining 
$92.9 \%$ is explained by other variables. Outside of this research model. Thus, it can be concluded that the R-Square with a value of 0.071 is included in the weak model because it has a value of less than 0.50 . Furthermore, R-square with a moderating effect, it can be seen that the R-Square value is 0.223 , which means that the influence of competitive strategy variables and supply chain management on company performance with supply chain management as a moderating variable can be explained by $22.3 \%$ and the remaining $77,7 \%$ is explained by other variables outside of this research model. Thus, it can be concluded that the R-Square with a value of 0.223 is also included in the weak model because it has a value of less than 0.50 .

\subsection{Hypothesis Testing}

Table 6

Result of Path Coefficients without Moderation and with Moderation

\begin{tabular}{cccccc}
\hline Model & Variable & & & Original Sample (O) & T Statistics \\
\hline \multirow{3}{*}{ Without Moderation } & SCM & $\rightarrow$ & Company Performance & 0,165 & 2,011 \\
& $\begin{array}{c}\text { Competitive } \\
\text { Strategy }\end{array}$ & $\rightarrow$ & Company Performance & 0,158 & 2,105 \\
& $\begin{array}{c}\text { MDR } \\
\text { AUE } \times \text { SC }\end{array}$ & $\rightarrow$ & Company performance & 0.281 & 2.731 \\
With Moderation & MDR PPC $\times$ SC & $\rightarrow$ & Company performance & 0.413 & 3.989 \\
& SCM & $\rightarrow$ & Company performance & -0.341 & 2.102 \\
& $\begin{array}{c}\text { Competitive } \\
\text { Strategy }\end{array}$ & $\rightarrow$ & Company performance & 0.191 & 2.629 \\
\hline
\end{tabular}

Source: Data processed by PLS, 2021

From the results of the table, it can be seen that the results of the path coefficients produced in the research model without a moderating effect and the research model with a moderating effect have different results. Table 6 shows that the relationship between competitive strategy and firm performance is a significant effect with a statistical value of 2.105 , greater than the required value, namely $1.96(2.105>1.96)$. The original sample estimate value is positive, namely 0.158 which indicates that the direction of the relationship between competitive strategy and company performance is positive. Thus, the hypothesis H1 in this study which states that competitive strategy has a significant positive effect on company performance is accepted. Furthermore, the relationship between supply chain management and company performance is a significant effect with a T-statistic value of 2.011 greater than the required value, namely $1.96(2.011>1.96)$. The original sample estimate value is positive, namely 0.165 which indicates that the direction of the relationship between supply chain management and company performance is positive. Thus, the $\mathrm{H} 2$ hypothesis in this study which states that supply chain management has a significant positive effect on company performance is accepted.

In addition, Table 6 shows that the relationship between competitive strategy and firm performance is a significant effect with a statistical value of 2.629 greater than the required value, namely $1.96(2.629>1.96)$. The original sample estimate value is positive, namely 0.191 which indicates that the direction of the relationship between competitive strategy and company performance is positive. Thus, the hypothesis $\mathrm{H} 1$ in this study which states that competitive strategy has a significant positive effect on company performance is accepted. Furthermore, the relationship between supply chain management and company performance has a significant effect with the T-statistic value of 2.102, greater than the required value, namely $1.96(2.102>1.96)$. The original sample estimate value is negative, which is -0.341 which indicates that the direction of the relationship between supply chain management and company performance is negative. This is proven to be different from the research model without a moderating effect, in which the original sample estimate value is positive, indicating that the direction of the relationship between supply chain management and company performance is positive. Hence, it can be said that the research model with a moderating effect that makes supply chain management a moderating variable makes a model for the relationship between supply chain management variables and company performance to be bad because it makes the original sample estimate value negative. However, even so, because the T-statistic is $>1.96$ and in theory according to Suharto (2013), with the existence of Supply Chain Management or supply chain management, the performance measurement system can work well and it is hoped that the company can make continuous improvements, so that to improve company performance can be supported by improving the implementation of supply chain management. Therefore, this research refers more to and supports the Path Coefficients table without a moderating effect which has a positive original sample estimate value because in theory the direction of the relationship between supply chain management and company performance is positive, so the $\mathrm{H} 2$ hypothesis in this study states that Supply chain management a significant positive effect on company performance is accepted. The next table shows that for the interaction variable between competitive strategy using the Asset Utilization Efficiency (AUE) indicator with supply chain management (SB AUE * SC) on company performance is a significant effect with a T-statistic value of 2.731 , greater than the required value, namely $1.96(2.731>1.96)$. The original sample estimate value is positive, which is 0.281 which indicates that the direction of the relationship between the SB AUE and SC interactions on the company's performance is positive. Likewise, the interaction variable between competitive strategies using the Price Premium Capability (PPC) indicator with supply chain management (SB PPC * SC) on company performance has a significant effect with a T-statistic value of 3.989, greater than the required value of $1.96(3,989>1.96)$. The original sample estimate value is positive which is equal to 0.413 which indicates that the 
direction of the relationship between the SB PPC and SC interaction with the company performance is positive. Thus, the hypothesis H3 in this study which states that Supply chain management has a significant positive effect in strengthening the relationship between competitive strategy and company performance is accepted.

\section{Discussion}

\subsection{The Effect of Competitive Strategy on Company Performance}

Based on the results of data processing using PLS, it can be concluded that the competitive strategy variable has a significant positive effect on company performance variables. This can be seen from the T-statistic value which is greater than 1.96 and the original sample which is positive. In table 7 the T-statistic value is 2.105 with the original sample being positive 0.158 for the model without moderating effect and in table 8 the T-statistic value is 2.629 with the original sample being positive 0.191 for the model with a moderating effect. Thus, the hypothesis $\mathrm{H} 1$ which states that competitive strategy has a significant positive effect on company performance in this study is accepted. This shows that the competitive strategy as measured by using two strategy measures, namely Asset Utilization Efficiency (low-cost strategy) and Price Premium Capability (differentiation strategy) states that the impact of Asset Utilization Efficiency (low-cost strategy) on firm performance shows that the sample company chooses a strategy low cost as a strategy to improve company performance. Whereas asset utilization efficiency indicates the importance of efficiency in corporate operational activities, which means that the more efficient costs spent in corporate activities, the smaller the utilization of assets used, so that the resulting corporate performance will increase (Suhartati \& Rosietta, 2012). In addition, the tendency to use a good differentiation strategy (Price Premium Capability) can improve the company's performance. This occurs because price premium capability indicates that the company is able to charge a price premium to customers by implementing innovative strategies to offer unique products and services so that customers can be charged at that price. By implementing this differentiation strategy, consumers will provide more value to the company for the products offered, Thus, creating a competitive advantage.

\subsection{Effect of Supply Chain Management on Company Performance}

Based on the results of data processing using PLS, it can be concluded that the Supply Chain Management variable has a significant positive effect on company performance variables. This can be seen from the T-statistic value which is greater than 1.96 and the original sample is positive. In table 7 the T-statistic value is 2.011 with the original sample being positive 0.165 for the model without moderating effect and in table 8 the T-statistic value is 2.102 with the original sample having a negative value of -0.341 for the model with a moderating effect, so it can be seen that the direction the two models are different. However, because in theory according to Suharto (2013) it is stated that with the existence of Supply Chain Management, the performance measurement system can run well. In this way, it is hoped that the company can make continuous improvements in which Supply Chain Management teaches how to form a good organizational network and business processes, so that to improve a company's performance it can be supported by increasing the implementation of supply chain management as well. In accordance with this, this study supports the results of the Path Coefficients model without a moderating effect which has a positive original sample value. Thus, the H2 hypothesis which states that Supply Chain Management has a significant positive effect on company performance in this study is accepted. This shows that optimizing company performance can be achieved if there is a good working relationship between the actors, namely: suppliers, factories, distributors, sellers and customers. Where a good working relationship can be done by implementing supply chain management, so from there it can be said that performance is one aspect that can be measured in supply chain management. In addition, this is also in line with the finding that satisfactory supply chain management excellence is directly related to superior organizational performance (Suhartati \& Rosietta, 2012; Soetjipto et al., 2021).

\subsection{The Effect of Competitive Strategy on Company Performance with Supply Chain Management as a Moderating Variable}

Based on the results of data processing using PLS, it can be concluded that the Supply Chain Management variable has a significant positive effect in strengthening the relationship between competitive strategy and company performance. This can be seen from the T-statistic value which is greater than 1.96 and has a positive original sample value. In table 8 , the interaction value between the SCM variable and the competitive strategy variable with the Asset Utilization Efficiency indicator, the T-statistic value is 2.731 with the original sample being positive 0.281 and for the interaction value between the SCM variable and the competitive strategy variable with the Price Premium Capability indicator, the T-statistic value is 3.989 with the original sample being positive 0.413 . Thus, the hypothesis $\mathrm{H} 3$ which states that supply chain management can have a significant positive effect in strengthening the relationship between competitive strategies and company performance in this study is accepted. Supply Chain Management is a management process that is very popular lately in increasing added value and competitiveness of the industry, where implementing supply chain management practices can provide fast service with high product variations and low costs, so that the company can survive amid increasingly fierce competition. Supply Chain Management as a new business perspective can be used as a tool to create competitive strategies in improving company performance, because Supply Chain Management emphasizes the implementation of a strategy which states that a strategy is needed to win the competition, including a strategy for managing quality so that 
competitiveness is achieved in the company. Supply chain management or supply chain management teaches how to form a good organizational network and business processes including production capabilities. Production capability with lower costs is one of the keys to a company's success in business competition because the more efficient costs are used in production activities, the higher the company's performance will be. The results of testing the interaction hypothesis between the variable supply chain management as a moderating variable and competitive strategy (asset utilization efficiency and Price Premium Capability) are proven to have an effect on corporate performance. This suggests that the supply chain management variable is a variable that can moderate the relationship between competitive strategy (asset utilization efficiency and price premium capability) and company performance (Tanwari, 2020). So that the sample companies carry out efficient supply chain management which focuses on efforts to meet consumer demand at the lowest price by minimizing total costs (low-cost strategy) and innovation strategies.

\section{Conclusion}

This study aims to determine the effect of competitive strategy on company performance with supply chain management as a moderating variable in manufacturing companies listed on the Indonesia Stock Exchange in 2015-2019. Competitive strategy variables are measured using the Asset Utilization Efficiency indicator (low-cost strategy) and the Price Premium Capability indicator (differentiation strategy) and the Supply Chain Management variable is measured by the Supply Chain Ratio, while the company's performance variables are measured using Tobin's Q Ratio. The sampling technique used was purposive sampling method. The data analysis technique used is descriptive analysis and statistical analysis using the Partial Least Square (PLS) method. Based on the results of statistical analysis testing and the discussion that has been done, the following conclusions are obtained. First, the results of testing the first hypothesis that examines the effect of competitive strategy on company performance, it is concluded that competitive strategy has a significant positive effect on company performance with indicators of Asset Utilization Efficiency (low-cost strategy) and Price Premium Capability (differentiation strategy). Second, the results of testing the second hypothesis which examines the effect of supply chain management on company performance, the conclusion is that supply chain management has a significant positive effect on company performance with the SC ratio indicator. Third, the results of testing the third hypothesis which examines the effect of competitive strategy on company performance with supply chain management as a moderating variable, it is concluded that supply chain management can have a significant positive effect in strengthening the relationship of competitive strategy with company performance.

This study has limitations, among others: (1) It only uses two dimensions of competitive strategy measures, namely Asset Utilization Efficiency (low-cost strategy) and Price Premium Capability (differentiation strategy); (2) This research is based on secondary data taken on the IDX, not based on observations so there is a possibility that it can be less in-depth about the correctness of implementing competitive strategies and supply chain management. Based on the limitations of the study, the suggestion that can be given for further research is that it is expected to consider the development of variable dimensions of competitive strategy measures other than those used in this study and to increase the observation period so that it can be known and analyzed in the long term. In addition, it is hoped that observations can be used so that it can be explained qualitatively to find out the truth of implementing competitive strategies and supply chain management in the company.

\section{References}

Adha, W. M. (2017). Integrasi Rantai Pasok terhadap Kinerja dan daya saing kakao. Jurnal Bisnis Darmajaya, 3(2), 146162.

Anton, F. X. (2010). Menuju teori stewardship manajemen. Majalah Ilmiah Informatika, 1(2).

Bharadwaj, A. S., Bharadwaj, S. G., \& Konsynski, B. R. (1999). Information technology effects on firm performance as measured by Tobin's q. Management science, 45(7), 1008-1024.

Blose, L. E., \& Shieh, J. C. (1997). Tobin's q-Ratio and market reaction to capital investment announcements. Financial Review, 32(3), 449-476.

Chang, H., Fernando, G. D., \& Tripathy, A. (2015). An empirical study of strategic positioning and production efficiency. Advances in Operations Research, 2015.

Chopra, S., \& Meindl, P. (2007). Supply chain management. Strategy, planning \& operation. In Das summa summarum des management (pp. 265-275). Gabler.

Davis, J. H., Schoorman, F. D., \& Donaldson, L. (1997). Toward a stewardship theory of management. Academy of Management review, 22(1), 20-47.

Ellinger, A. E., Natarajarathinam, M., Adams, F. G., Gray, J. B., Hofman, D., \& O’Marah, K. (2011). Supply chain management competency and firm financial success. Journal of Business Logistics, 32(3), 214-226.

Ghatebi, M., Ramezani, E., \& Shiraz, M. A. E. (2013). Impact of Supply Chain Management Practices on Competitive Advantage in Manufacturing Companies of Khuzestan Province. Interdisciplinary Journal of Contemporary Research Business, 5(6), 269-274.

Ghozali, I. (2008). Structural Equation Modeling:Metode Alternatif dengan Partial Least Square. Badan Penerbit Universitas Diponegoro.

Gitman, L. J., \& Zutter, C. J. (2012). Principle of Managerial Finance. Essex, England.

Irham, F. (2011). Manajemen kinerja teori dan aplikasi. Bandung: Alfabeta. 
Jermias, J., \& Gani, L. (2004). Integrating business strategy, organizational configurations and management accounting systems with business unit effectiveness: a fitness landscape approach. Management accounting research, 15(2), 179200.

Le Roy, F., \& Czakon, W. (2016). Managing coopetition: the missing link between strategy and performance. Industrial Marketing Management, 53(1), 3-6.

Li, S., Ragu-Nathan, B., Ragu-Nathan, T. S., \& Rao, S. S. (2006). The impact of supply chain management practices on competitive advantage and organizational performance. Omega, 34(2), 107-124.

McLeod Jr, R. (1996). Sistem Informasi Manajemen: Studi Sistem Informasi Berbasis Komputer Jilid I. Jakarta: PT. Prenhallindo.

Oliver, R. K., \& Webber, M. D. (1982). Supply-chain management: logistics catches up with strategy. Outlook, 5(1), 4247.

Perry II, J. F. (2012). The impact of supply chain business processes on competitive advantage and organizational performance.

Pujawan, I. N. (2005). The Effect of Different Payment Terms on Order Variability in a Supply Chain. In Successful Strategies in Supply Chain Management (pp. 90-108). IGI Global.

Raharjo, E. (2007). Teori Agensi dan Teori Stewarship dalam Perspektif Akuntansi. Fokus Ekonomi: Jurnal Ilmiah Ekonomi, 2(1).

Rahmasari, L. (2011). Pengaruh supply chain management terhadap kinerja perusahaan dan keunggulan bersaing (Studi kasus pada industri kreatif di Provinsi Jawa Tengah). Majalah Ilmiah Informatika, 2(3).

Rasid, S. Z. A., Isa, C. R., \& Ismail, W. K. W. (2014). Management accounting systems, enterprise risk management and organizational performance in financial institutions. Asian Review of Accounting.

Render, B., \& Heizer, J. (2005). Manajemen Operasional.

Robert, A. N., \& Vijay, G. (2012). Management Control System (Sistem Pengendalian Manajemen). Salemba Empat, Jakarta.

Siagian, Y. M. (2005). Aplikasi Supply Chain Management dalam Dunia Bisnis. Grasindo. Jakarta.

Simchi-Levi, D., Kaminsky, P., Simchi-Levi, E., \& Shankar, R. (2008). Designing and managing the supply chain: concepts, strategies and case studies. Tata McGraw-Hill Education.

Soetjipto, N., Sulastri, S., Prastyorini, J., Soedarmanto, S., \& Riswanto, A. (2021). Implementation of enterprise human resources management standards to achieve supply chain excellence in fertilizer companies in Indonesia. Uncertain Supply Chain Management, 9(1), 107-114.

Sudiyatno, B., \& Puspitasari, E. (2010). Tobin's q dan altman z-score sebagai indikator pengukuran kinerja perusahaan. Kajian Akuntansi, 2(1), 247233.

Suhartati, T., \& Rosietta, H. (2012). Pengaruh Strategi Bersaing Terhadap Hubungan Antara Supply Chain Management Dan Kinerja. Universitas Indonesia. Simposium Nasional Akuntansi XV.

Suharto, R. J. (2013). Analisa Pengaruh Supply Chain Management terhadap keunggulan bersaing dan kinerja perusahaan. Business Accounting Review, 1(2), 226-235.

Tanwari, A. (2020). A Study on Assessing the Relationship between Green Marketing and Brand Loyalty in Manufacturing Sector of Greece: A Moderating Role of Green Supply Chain Practices. Arthatama, 4(1), 44-55.

Tewal, B. (2010). Pengaruh strategi bersaing dan inovasi terhadap kinerja perusahaan perhotelan di Sulawesi Utara. Jurnal Aplikasi Manajemen, 8(2), 464-470.

Ulfa, M. (2015). Pengaruh Strategi Bersaing Terhadap Kinerja Perusahaan Dengan Supply Chain Management Sebagai Variabel Moderating Pada Perusahaan Manufaktur Di Bursa Efek Indonesia (Doctoral dissertation, STIE Perbanas Surabaya)

Wheelen, T. L., Hunger, J. D., Hoffman, A. N., \& Bamford, C. E. (2017). Strategic management and business policy (p. 55). Boston, MA: pearson.

Wright, P., Kroll, M., Mukherji, A., \& Pettus, M. L. (2009). Do the contingencies of external monitoring, ownership incentives, or free cash flow explain opposing firm performance expectations?. Journal of Management \& Governance, 13(3), 215-243.

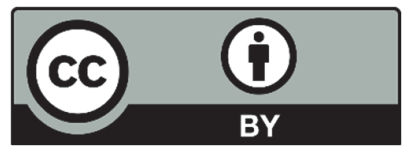

(C) 2021 by the authors; licensee Growing Science, Canada. This is an open access article distributed under the terms and conditions of the Creative Commons Attribution (CC-BY) license (http://creativecommons.org/licenses/by/4.0/). 